\title{
Research on Correlations between Academicians' Levels of Organisational Commitment and Their Intention to Quit Their Job: A Comparison of State and Foundation Universities
}

\author{
Mustafa $\operatorname{Koc}^{1}$ \\ ${ }^{1}$ School of Physical Education and Sports, Adıyaman University, Adıyaman, Turkey \\ Correspondence: Mustafa Koc, School of Physical Education and Sports, Adryaman University, Adryaman, \\ Turkey. E-mail: mustafakoc.7483@gmail.com
}

Received: August 16, 2017

Accepted: September 30, 2017 Online Published: October 24, 2017

doi:10.5539/jel.v7n1p163

\author{
URL: https://doi.org/10.5539/jel.v7n1p163
}

\begin{abstract}
This study aims to demonstrate the correlations between academicians' organisational commitment and their intention to resign from their job. For this purpose, first the concepts of organisational commitment and quitting the job were considered within the framework of relevant literature, and then hypotheses for the correlations were developed.

276 lecturers in total 198 of whom were teaching in faculties or departments of sport sciences and 78 of whom were teaching in foundation universities were included in this study.

A personal information form in addition to Turnover Intention Scale developed by Rosin and Korabick (1995) and adapted into Turkish by Tanriöver (2005), and Organisational Commitment Scale developed by Meyer and Allen (1997) and adapted into Turkish by Varol (2010) were used for our purposes.

In conclusion, it was found that academicians' intention to quit their job was low but their organisational commitment levels were high and that they had emotional commitment most — which was followed by normative commitment and continuance commitment. Lecturers employed in foundation universities had higher levels of intention to quit their job than those employed in state universities. Lecturers working in state universities had higher levels of emotional commitment than those working in foundation universities. It was also found that lecturers' rate of quitting the job was reduced as their levels of emotional and normative commitment increased in both state and foundation universities.
\end{abstract}

Keywords: organisational commitment, intention to quit the job

\section{Introduction}

Organisations are the social constructs which come together so as to attain certain goals. Now that it is humans who play the main role in those constructs, attaining the goals set and operation of the organisation depend on the availability of employees who strictly adhere to the values of the institution and who internalise the goals and targets of the institution as their own goals and targets. At this point, the concept of "organisational commitment", which may be defined as "the combination of an employee's desire to remain as the member of an organisation, his/her wish to make more efforts for the organisation than expected and his/her belief in the goals and values of the organisation" becomes important (Meyer \& Allen, 2004, p. 2).

Organisational commitment has been subject of research as a way of organisational behaviour and as one of the most important issues of organisational psychology. Because organisational commitment is considered as an important step in attaining organisational goals, importance attached to the issue is increasing day by day. Causes for organisational commitment and its output are researched in many cultures (Ermiş et al., 2015).

Organisational commitment represents the power of ties an employee feels for the organisation he/she works for. Besides, it is also necessary for institutions such as universities - which aim to produce high quality output - to be able to incorporate high quality work force into their body, to be able to keep them in the organisation, to increase the "positive feelings" individuals have for their job, and to be able to get the maximum performance from them (Ermiş, 2014). 
It is generally regarded in administrative science research that the components of organisational commitment separately and in interaction with each other have effects of many organisational behaviours and attitudes. The major variable associated with organisational commitment is the intention to quit one's job (Allen \& Meyer, 1993).

Such organisational behaviours as organisational identification, organisational commitment, organisational citizenship and intention to quit the job-which employees in institutions perceive within their organisation - are considered important for the success and future of the organisation; and administrators take on great responsibility in whether such situations arise or not in organisations. Therefore, it is important to determine the extent to which employees have commitment to their organisation, have organisational identity and tend to quit their job. This can help organisation administrators to understand their employees better and make employees more effective and efficient (Tolukan, Şahin, \& Koç, 2016).

Setting out from this point, this study analyses the correlations between organisational commitment levels of lecturers teaching in Physical Education and Sport departments of universities and their intention to quit their job.

\subsection{Organisational Commitment}

The reason for why organisational commitment is a subject of research is that it is regarded as a factor contributing positively to organisations (Marciori \& Henkin, 2004).

Organisational commitment described in such concepts as faithfulness to an organisation, sacrificing, devotion and participation - is defined in the literature as internalising the targets and values of an organisation, making efforts as a part of the organisation and feeling like a strong family member (Swailes, 2002).

Organisational commitment: is the degree to which an employee sets up a union of strength with an organisation and feels a part of the organisation (Schermerhorn et al., 1994, p. 144).

Is an employee's identification with an organisation's goals and values as the primary target by desiring to remain in the organisation without any financial worries (Gaertner \& Nollen, 1989, p. 975).

\subsubsection{Dimensions of Organisational Commitment}

Organisational commitment is analysed from different aspects in relevant literature. One of the most commonly used models in the literature is three-component organisational commitment model developed by Meyer and Allen. Contending that organisational commitment is based on 3 main components, Allen and Meyer lists the components as emotional commitment, continuance commitment and normative commitment (Allen \& Meyer, 1990).

Setting out from this point, the model developed by Meyer and Allen was used in this study. Of the three components used in analysing organisational commitment, emotional commitment expresses an emotional orientation showing that individuals are identified with their organisation, that they feel happy to be a member of their organisation and that they are strongly faithful to their organisation. Emotional commitment involves employees' acceptance of organisational goals and values and their making extraordinary efforts on behalf of their organisation. Continuance commitment, on the other hand, indicates individuals' continuation of membership in case they leave the organisation due to probable costs and/or alternative job opportunities. Continuance commitment emerges in consequence of an employee's evaluation of his/her desire to remain in the organisation, sum of his/her investments in the organisation, his/her probable losses in case of leaving the organisation and restrictedness of comparable alternatives. Normative commitment expresses commitment individuals have because they feel obligatory due to moral obligation (Allen \& Meyer, 1990; Meyer \& Allen, 2004).

\subsection{Turnover Intention}

The concept of "turnover intention" which is considered as the dependent variable in this study expresses a "conscious and dignified decision or intention to leave an organisation" (Barttlett, 1999, p. 70).

Turnover intention involves the process of decision-making which results in setting up temporary connections between leaving the organisation or intellectual and behavioural activities. It is the probability of one's leaving the organisation (Sökmen \& Şimşek, 2017).

An employee's quitting the job is an undesired situation. Losing a hired and orientated employee means selection and orientation process for the next employee. For an organisation, losing an employee means extra time and energy and financial loss. In the same way, at universities, an academician's having the intention to transfer from one school into another can cause the academician to spend his/her energy in search for a school. This in turn can 
influence the academician's focus on educational-instructional activities in a negative way since he/she has the thought that he/she will go (Töremen \& Demir, 2016).

It is emphasised in many studies that turnover intention (or the intention to quit the job) is an important variable for both employees and organisations. A teacher's leaving the job, for instance, can strike a great blow to the quality of education because this results in students having lower quality education —which is a serious problem of education (Hsiao, Auld, \& Ma, 2015; Liu \& Onwuegbuzie, 2012).

\subsection{Correlations}

According to Allen and Meyer (1990), the only point for which researchers have shared views in terms of conceptualising organisational commitment is that employees' intention to remain in their organisation will increase in parallel to the increase in their organisational commitment.

It was shown in many studies that there were reverse and significant correlations between all sub-dimensions of organisational commitment and turnover intention, and it was regarded in this context that organisational commitment was the most important predictor of turnover intention. Some of the studies conducted previously stress the role of organisational commitment as a factor diminishing intention to quit the job (Meyer et al., 2002).

While organisational commitment—a variable in this study—indicates employees' tendency to continue working, turnover intention indicates one's tendency to quit the job. Seen from this perspective, turnover intention and organisational commitment are the concepts which are completely opposite in meaning. Thus, these two concepts are considered together in many studies. Conclusions in studies mostly suggest that there are negative correlations between turnover intention and organisational commitment (Tett \& Meyer, 1993; Schwepker, 2001; Cole \& Bruch, 2006; Joo \& Park, 2010).

Consequently, organisational commitment is brought into prominence in the literature as the most important factor in diminishing turnover intention - which should be established in an organisation.

\section{Material \& Methods}

This section included information on research model, study group, data collection tools and data analysis.

\subsection{Research Model}

This study aims to determine the correlations between turnover intentions of lecturers teaching in the sport sciences faculties or departments of state and foundation universities and their organisational commitment levels and whether or not these variables differ significantly according to the types of universities. Therefore, this study uses relational survey model —one of the general survey models. Relational survey models — which are also called correlational models - are the studies in which correlations between two or more variables are investigated without interventions in these variables (Büyüköztürk, 2006).

\subsection{Study Group}

This study was conducted with 276 lecturers in total 198 of whom were teaching in faculties or departments of sport sciences and 78 of whom were teaching in foundation universities.

\subsection{Data Collection Tools}

The data were collected from lecturers through personal information form, Turnover Intention Scale and Organisational commitment Scale in this study.

\subsubsection{Personal Information Form}

Information on the types of universities the lecturers were employed, their gender, marital status and whether or not they were in administrative positions in their university were obtained by means of personal information form in this study.

\subsubsection{Turnover Intention Scale}

Turnover intention Scale developed by Rosin and Korabick (1995) was used to determine turnover intentions of lecturers teaching in state and foundation universities. The scale was adapted into Turkish by Tanriöver (2005). The four-item scale was composed of 5-pointed Likert type items. Because one of those items $(\mathrm{m} 4)$ had negative properties, it was coded reversely and excluded from analyses. Tanriöver (2005) calculated the reliability for the answers to scale items with Cronbach Alpha and found it as 0.930 .

This study aimed to determine turnover intentions of lecturers working in Sport Sciences faculties or departments of state and foundation universities. First exploratory factor analysis was performed to validate the answers lecturers gave to the items of turnover intention scale. In consequence, it was found that the scale items were one 
dimensional and that $69.159 \%$ of the total variance was explained. It was found that factor loads for the items were between 0.766 and 0.888 . After that, confirmatory factor analysis was performed and accordingly it was found that all the items had significant $t$ values. Standardised regression coefficients were found to range between 0.41 and 0.82. Fit indices $\left(\mathrm{CFI}=0.98 ; \mathrm{NFI}=0.98 ; \mathrm{GFI}=0.97 ; \mathrm{X}^{2} / \mathrm{df}=3.48\right)$ also showed that model-data fit was attained. Cronbach Alpha coefficient was calculated so as to find the reliability of the responses given by the lecturers to the scale items, and it was found as 0.848 .

Based on all this, it was found that lecturers gave valid and reliable answers to turnover scale.

\subsubsection{Organisational Commitment Scale}

Organisational Commitment Scale developed by Meyer and Allen (1997) was used in determining the organisational commitment levels of the lecturers. The scale was adapted into Turkish by Varol (2010). The scale contained 18 items in 5-pointed Likert type. There were three dimensions in the scale: emotional commitment, continuance commitment and normative commitment.

Exploratory factor analysis was performed so as to determine the validity of the responses lecturers gave to the scale items. Accordingly, the items were found to have three dimensions and that $59.343 \%$ of the total variance was explained. After that, confirmatory factor analysis was conducted for the 18-item, three-dimension scale, and it was found that the model was in general confirmed by lecturers' responses $(\mathrm{CFI}=0.94$; $\mathrm{NFI}=0.93$; $\mathrm{GFI}=0.95$; $\left.\mathrm{X}^{2} / \mathrm{df}=4,48\right)$. Cronbach Alpha coefficient was calculated in order to find the reliability levels of the lecturers answers to the scale items, and it was found to be 0.925 for emotional commitment, 0.675 for continuance commitment, and 0.703 for normative commitment. Cronbach Alpha coefficient for the lecturers' answers to 18 items of the scale was found as 0.801 .

Thus, it was found that lecturers gave valid and reliable responses to the scale items.

\subsection{Analysis of the Data}

First, descriptive statistics (minimum, maximum, mean and standard deviation) were calculated in order to determine the turnover levels of the lecturers working in state universities. Independent sample $t$ test was performed so as to find whether or not turnover intentions and organisational commitment levels of lecturers working in state universities and of those working in foundation universities differed significantly. In addition to that, Pearson's Correlation Coefficient was also calculated to analyse the correlations between academicians' turnover intention and their levels of organisational commitment.

\section{Findings}

\subsection{What Is the Level of Turnover Intention and Organisational Commitment of Lecturers Working in State} Universities?

Descriptive statistics were calculated so as to determine the turnover intention and organisational commitment levels of lecturers working in state universities, and the results are shown in Table 1 below.

Table 1. Descriptive statistics for the turnover intention and organisational commitment levels of lecturers working in state universities

\begin{tabular}{llcccccc}
\hline Scale & & Item number & $\mathbf{N}$ & Min. & Max. & $\overline{\mathbf{X}}$ & SD \\
& & & & & & & \\
\hline Turnover intention & & 4 & 198 & 4.00 & 20.00 & 7.45 & 3.88 \\
\hline \multirow{3}{*}{ Organisational commitment } & Emotional commitment & 6 & 198 & 6.00 & 30.00 & 23.70 & 5.39 \\
& Continuance commitment & 6 & 198 & 6.00 & 27.00 & 14.44 & 4.84 \\
& Normative commitment & 6 & 198 & 6.00 & 29.00 & 20.01 & 4.65 \\
& Organisational commitment & 18 & 198 & 27.00 & 82.00 & 57.51 & 10.44 \\
\hline
\end{tabular}

According to the Table, turnover intention scores of lectures working in state universities range between 4.00 and 20.00 and the average is $7.45 \pm 3.88$. Thus, it was found that those lecturers had low levels of turnover intentions (7.45 over 20$)$.

It was found accordingly that emotional commitment scores of lecturers working in state universities ranged between 6.00 and 30.00 with an average of $23.70 \pm 5.39$. Accordingly, continuance commitment scores were 
between 6.00 and 26.00 with an average of $14.44 \pm 4.84$. Those lecturers' normative commitment levels were between 6.00 and 29.00 with an average of $20.01 \pm 4.65$. On examining lecturers levels of organisational commitment, it was found that the values were between 27.00 and 82.00 with an average of $57.51 \pm 10.44$. On examining the averages, it was found that lecturers working in state universities had emotional commitment mostwhich was followed by normative and continuance commitment respectively.

3.2 What Is the Level of Turnover Intention and Organisational Commitment of Lecturers Working in State Universities?

Pearson's Moments Coefficient was calculated so as to find the correlations between the turnover intentions of lecturers working in state universities - whose views were obtained in this research-and their levels of organisational commitment. The results are shown in Table 2 below.

Table 2. Correlations between the turnover intention and organisational commitment levels of lecturers working in state universities

\begin{tabular}{|c|c|c|c|c|c|c|}
\hline Variables/Values & & Turnover & $\begin{array}{l}\text { Emotional } \\
\text { commitment }\end{array}$ & $\begin{array}{l}\text { Continuance } \\
\text { commitment }\end{array}$ & $\begin{array}{l}\text { Normative } \\
\text { commitment }\end{array}$ & $\begin{array}{c}\text { Organisational } \\
\text { commitment }\end{array}$ \\
\hline & $\mathrm{r}$ & 1 & -0.603 & 0.178 & -0.371 & -0.395 \\
\hline \multirow[t]{3}{*}{ Turn over } & $\mathrm{p}$ & . & $0.000^{*}$ & 0.012 & $0.000 *$ & $0.000 *$ \\
\hline & $\mathrm{N}$ & 198 & 198 & 198 & 198 & 198 \\
\hline & $\mathrm{r}$ & & 1 & -0.042 & 0.554 & 0.744 \\
\hline \multirow[t]{3}{*}{$\begin{array}{l}\text { Emotional } \\
\text { commitment }\end{array}$} & $\mathrm{p}$ & & . & 0,559 & $0,000^{*}$ & $0.000 *$ \\
\hline & $\mathrm{N}$ & & 198 & 198 & 198 & 198 \\
\hline & $\mathrm{r}$ & & & 1 & 0.225 & 0.535 \\
\hline \multirow[t]{3}{*}{$\begin{array}{l}\text { Continuance } \\
\text { commitment }\end{array}$} & $\mathrm{p}$ & & & . & $0.001 *$ & $0.000^{*}$ \\
\hline & $\mathrm{N}$ & & & 198 & 198 & 198 \\
\hline & $\mathrm{r}$ & & & & 1 & 0.834 \\
\hline \multirow[t]{3}{*}{$\begin{array}{l}\text { Normative } \\
\text { commitment }\end{array}$} & $\mathrm{p}$ & & & & $\cdot$ & $0.000^{*}$ \\
\hline & $\mathrm{N}$ & & & & 198 & 198 \\
\hline & $\mathrm{r}$ & & & & & 1 \\
\hline \multirow{2}{*}{$\begin{array}{l}\text { Organisational } \\
\text { commitment }\end{array}$} & $\mathrm{p}$ & & & & & $\cdot$ \\
\hline & $\mathrm{N}$ & & & & & 198 \\
\hline
\end{tabular}

According to Table 2, there are negative, medium level correlations $(r=-0.603 ; p<0.05)$ between the turnover intention and emotional commitment of lecturers working in state universities. There are positive but low level correlations between their turnover intention and continuance commitment $(\mathrm{r}=0.178 ; \mathrm{p}<0.05)$, and negative, low level correlations between their turnover intention and normative continuance $(\mathrm{r}=-0.371 ; \mathrm{p}<0.05)$ and organisational commitment $(\mathrm{r}=-0.395 ; \mathrm{p}<0.05)$.

As clear from the Table, there are no correlations between lecturers' emotional commitment and continuance commitment $(\mathrm{r}=-0.042 ; \mathrm{p}>0.05)$. Positive, medium level correlations were found between lecturers' emotional commitment and normative commitment $(\mathrm{r}=0.554 ; \mathrm{p}<0.05)$. It was also found that there were positive and low level correlations between their continuance commitment and normative commitment $(\mathrm{r}=0.225 ; \mathrm{p}<0.05)$.

Organisational commitment of the lecturers working in state universities was found to be most correlated with normative commitment $(\mathrm{r}=0.834 ; \mathrm{p}<0.05)$ which was followed by emotional commitment $(\mathrm{r}=0.774 ; \mathrm{p}<0.05)$. Medium level correlations were found between organisational commitment and continuance commitment $(\mathrm{r}=0.535 ; \mathrm{p}<0.05)$. The correlations were positive. 


\subsection{What Is the Level of Turnover Intention and Organisational Commitment of Lecturers Working in Foundation Universities?}

Descriptive statistics were calculated so as to find the correlations between the turnover intentions of lecturers working in foundation universities - whose views were obtained in this research - and their levels of organisational commitment. The results are shown in the Table below.

Table 3. Descriptive statistics calculated in relation to the turnover intentions of lecturers working in foundation universities and their levels of organisational commitment

\begin{tabular}{llcccccc}
\hline Scale & & Item number & $\mathbf{N}$ & Min. & Max. & $\overline{\mathbf{X}}$ & SD \\
\hline Turnover intention & & 4 & 78 & 4.00 & 20.00 & 9.82 & 4.15 \\
\hline \multirow{3}{*}{$\begin{array}{l}\text { Organisational } \\
\text { commitment }\end{array}$} & Emotional commitment & 6 & 78 & 6.00 & 30.00 & 20.40 & 6.44 \\
& Continuance commitment & 6 & 78 & 6.00 & 27.00 & 16.08 & 4.68 \\
& Normative commitment & 6 & 78 & 7.00 & 28.00 & 19.19 & 4.76 \\
& Organisational commitment & 18 & 78 & 31,00 & 76,00 & 55,67 & 10,89 \\
\hline
\end{tabular}

A close examination of Table 2 makes it clear that the turnover intention of lecturers working in foundation universities range between 4.00 and 20.00 and that the average is $9.82 \pm 4.15$. In other words, the lecturers working in foundation universities were found to have low levels of turnover intention (9.82 over 209).

According to the Table, the emotional commitment scores of the lecturers working in foundation universities are between 6.00 and 30.00 with an average of $20.40 \pm 6.44$. Their levels of continuance commitment are between 6.00 and 27.00 and the average is $16.08 \pm 4.68$. It was also found that the lecturers normative commitment scores ranged between 7.00 and 28.00 with an average of $19.19 \pm 4.76$. Their total scores for organisational commitment ranged between 31.00 and 76.00 with an average of $55.67 \pm 10.89$.

3.4 What Is the Level of Turnover Intention and Organisational Commitment of Lecturers Working in Foundation Universities?

Pearson's Moments Coefficient was calculated so as to find the correlations between the turnover intentions of lecturers working in foundation universities and their levels of organisational commitment. The results are shown in Table 4 below.

Table 4. Correlations between the turnover intention and organisational commitment levels of lecturers working in foundation universities

\begin{tabular}{|c|c|c|c|c|c|c|}
\hline Variables/Values & & Turnover & $\begin{array}{c}\text { Emotional } \\
\text { commitment }\end{array}$ & $\begin{array}{l}\text { Continuance } \\
\text { commitment }\end{array}$ & $\begin{array}{l}\text { Normative } \\
\text { commitment }\end{array}$ & $\begin{array}{c}\text { Organisational } \\
\text { commitment }\end{array}$ \\
\hline \multirow{3}{*}{ Turn over } & $\mathrm{r}$ & 1 & -0.636 & 0.069 & -0.703 & -0.654 \\
\hline & $\mathrm{p}$ & . & $0.000^{*}$ & 0.549 & 0.000 & 0.000 \\
\hline & $\mathrm{N}$ & 78 & 78 & 78 & 78 & 78 \\
\hline \multirow{3}{*}{$\begin{array}{l}\text { Emotional } \\
\text { commitment }\end{array}$} & $\mathrm{r}$ & & 1 & -0.125 & 0.707 & 0.847 \\
\hline & $\mathrm{p}$ & & . & 0.274 & $0.000^{*}$ & $0.000^{*}$ \\
\hline & $\mathrm{N}$ & & 78 & 78 & 78 & 78 \\
\hline \multirow{3}{*}{$\begin{array}{l}\text { Continuance } \\
\text { commitment }\end{array}$} & $\mathrm{r}$ & & & 1 & -0.074 & 0.324 \\
\hline & $\mathrm{p}$ & & & . & 0.522 & $0.004 *$ \\
\hline & $\mathrm{N}$ & & & 78 & 78 & 78 \\
\hline \multirow{3}{*}{$\begin{array}{l}\text { Normative } \\
\text { commitment }\end{array}$} & $\mathrm{r}$ & & & & 1 & 0.823 \\
\hline & $\mathrm{p}$ & & & & . & $0.000^{*}$ \\
\hline & $\mathrm{N}$ & & & & 78 & 78 \\
\hline
\end{tabular}




\begin{tabular}{llc}
\hline Organisational & $\mathrm{r}$ & 1 \\
commitment & $\mathrm{p}$ & $\cdot$ \\
& $\mathrm{N}$ & 78 \\
\hline
\end{tabular}

$* \mathrm{p}<0,05$.

According to Table 4, there are medium level negative correlations between turnover intentions of lecturers working in the faculties or departments of sport sciences and their emotional commitment $(\mathrm{r}=-0.636 ; \mathrm{p}<0.05)$. That is to say, it was found that lecturers' intention to quit their job diminished in parallel to the increase in their levels of emotional commitment. No significant correlations were found between lecturers' turnover intentions and their continuance commitment $(\mathrm{r}=0.069 ; \mathrm{p}>0.05)$. However, high level negative correlations were found between the turnover intentions of lecturers working in foundation universities and their normative commitment $(\mathrm{r}=-0.703$; $\mathrm{p}<0.05$ ). In a similar vein, it was found that their turnover levels decreased in parallel to the increase in their normative commitment. Medium level negative correlations were found between turnover levels and total scores for organisational commitment $(\mathrm{r}=-0.654 ; \mathrm{p}<0.05)$.

While no significant correlations were found between those lecturers' emotional commitment and continuance commitment $(\mathrm{r}=-0.125 ; \mathrm{p}>0.05)$, positive and high level correlations were found with normative commitment $(\mathrm{r}=0.707 ; \mathrm{p}<0.05)$.

On analysing the correlations between the organisational commitment of lecturers working in foundation universities and the sub-dimensions of organisational commitment, it was found that the strongest correlations were between emotional commitment $(\mathrm{r}=0.847 ; \mathrm{p}<0.05)$ and normative commitment $(\mathrm{r}=0.823 ; \mathrm{p}<0.05)$. Negative and low level correlations were found between organisational commitment and continuance commitment $(\mathrm{r}=0.324$; $\mathrm{p}<0.05)$.

\section{A Comparison of Lecturers Working in State Universities and Those Working in Foundation Universities.}

\subsection{Are There Any Significant Differences between the Turnover Intentions of Lecturers Working in State} Universities and of Those Working in Foundation Universities?

Independent sample $t$ test was calculated so as to find whether or not there were any significant differences between the turnover intentions of lecturers working in state universities and of those working in foundation universities. Table 5 below shows the results obtained.

Table 5. Independent sample t test results for lecturers' turnout intentions according to the institutions they work

\begin{tabular}{llccccc}
\hline Scale & Institutions & $\mathbf{N}$ & $\overline{\mathbf{X}}$ & $\mathbf{S D}$ & $\mathbf{t}$ & $\mathbf{p}$ \\
\hline Turnover intention & State university & 198 & 7.45 & 3.88 & \multirow{2}{*}{4.481} & $0.000^{*}$ \\
& Foundation university & 78 & 9.82 & 4.15 & & \\
\hline
\end{tabular}

$* \mathrm{p}<0.05$.

As is evident from the Table, turnout intentions of lecturers differ significantly according to the type of universities they work $\left(\mathrm{t}_{(274)}=4.481 ; \mathrm{p}<0.05\right)$. An analysis of the average scores showed that the lecturers working in the faculties or departments of sport sciences of foundation universities $(9.82 \pm 4.15)$ had higher levels of turnover intention than those working in state universities (7.45 \pm 3.88$)$.

3.6 Are There Any Significant Differences between the Organisational Commitment of Lecturers Working in State Universities and of Those Working in Foundation Universities?

Independent sample $t$ test was calculated so as to find whether or not there were any significant differences between the organisational commitment levels of lecturers working in state universities and of those working in foundation universities. Table 6 below shows the results. 
Table 6. The results for independent sample $t$ test calculated for the organisational commitment levels of lecturers according to the institution they work

\begin{tabular}{|c|c|c|c|c|c|c|c|}
\hline Scale & & Institution & $\mathbf{N}$ & $\overline{\mathbf{X}}$ & SD & $\mathbf{t}$ & $\mathbf{p}$ \\
\hline \multirow{8}{*}{ Organisational commitment } & \multirow[t]{2}{*}{ Emotional commitment } & State university & 198 & 23.70 & 5.39 & \multirow{2}{*}{4.334} & \multirow{2}{*}{$0,000^{*}$} \\
\hline & & Foundation university & 78 & 20.40 & 6.44 & & \\
\hline & \multirow[t]{2}{*}{ Continuance commitment } & State university & 198 & 13.80 & 4.76 & \multirow{2}{*}{3.596} & \multirow{2}{*}{$0,000^{*}$} \\
\hline & & Foundation university & 78 & 16.08 & 4.68 & & \\
\hline & \multirow[t]{2}{*}{ Normative commitment } & State university & 198 & 20.01 & 4.65 & \multirow{2}{*}{1.299} & \multirow{2}{*}{0,195} \\
\hline & & Foundation university & 78 & 19.19 & 4.76 & & \\
\hline & \multirow[t]{2}{*}{ Organisational commitment } & State university & 198 & 57.51 & 10.44 & \multirow{2}{*}{1.302} & \multirow{2}{*}{0,194} \\
\hline & & Foundation university & 78 & 55.67 & 10.89 & & \\
\hline
\end{tabular}

$* p<0.05$.

Accordingly, the emotional commitment $\left(\mathrm{t}_{(274)}=4.334 ; \mathrm{p}<0.05\right)$ and continuance commitment $\left(\mathrm{t}_{(274)}=3.596 ; \mathrm{p}<0.05\right)$ of the lecturers included in the study differ significantly according to the types of universities they work. On analysing the average scores it was found that the lecturers working in state universities (23.70 5 .39) had higher levels of emotional commitment than those working in foundation universities (20.40土6.44). On the other hand, it was found that lecturers working in foundation universities (16.08 \pm 4.68$)$ had higher levels of continuance

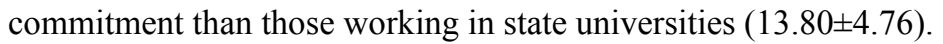

It was also found that the normative commitment of lecturers $\left(\mathrm{t}_{(274)}=1.299 ; \mathrm{p}>0.05\right)$ and total scores for their organisational commitment $\left(\mathrm{t}_{(274)}=1.302 ; \mathrm{p}>0.05\right)$ did not differ significantly.

\section{Discussion and Conclusions}

It was found in this study that there were medium level negative correlations between turnover intentions of lecturers working in state universities and their emotional commitment $(\mathrm{r}=0.603 ; \mathrm{p}<0.05)$, and low level negative correlations with normative commitment $(\mathrm{r}=-0.371 ; \mathrm{p}<0.05)$ and with organisational commitment $(\mathrm{r}=-0.395$; $\mathrm{p}<0.05)$.

Medium level negative correlations were found between turnover intentions of lecturers working in the sport sciences faculties or departments of foundation universities and their emotional commitment $(r=-0.636 ; p<0.05)$. It was also found that there were high level negative correlations between their turnover intentions and normative commitment $(\mathrm{r}=-0.703 ; \mathrm{p}<0.05)$. In addition to that, negative and medium level correlations were found between those lecturers' turnover intentions and their total scores for organisational commitment $(\mathrm{r}=-0.654 ; \mathrm{p}<0.05)$.

It was found for participants from both state and foundation universities that lecturers' levels of quitting their job fell as their emotional and normative commitment levels rose (see Tables 2-4).

Studies conducted point out that organisational commitment was positively correlated primarily with job satisfaction and productivity (Lingard \& Lin, 2004, p. 410) and it is observed that organisational commitment has significant effects on quitting one's job (Sökmen \& Şimşek, 2017).

Parasiz et al. (2016) found that academicians' turnover intentions fell as their emotional and normative commitment rose. They found that that there were medium level negative correlations between emotional commitment and turnover intentions $(\mathrm{r}=-0.625 ; \mathrm{p}<0.05)$ and low level negative correlations between normative commitment and turnover intentions $(\mathrm{r}=-0.393 ; \mathrm{p}<0.05)$ (Parasiz et al., 2016).

Özdemir and Yaylı (2014) found high level negative correlations between emotional commitment and turnover intention ( $\mathrm{r}=-0.709)$, and weak negative correlations with normative commitment $(\mathrm{r}=-0.436)$. Das et al. (2013) also demonstrated that there were negative correlations between organisational commitment and turnover intention. All these results are supportive of the results obtained in this study.

This situation shows that employees' turnover intention tends to fall as their emotional and normative commitment rise. Besides, consistent with relevant literature, it is confirmed that employees who have an increase in their emotional commitment to their organisation experience a decrease in their turnover intentions. The responsibility of an organisation wishing not to lose a good employee is to establish organisational commitment and to keep a good employee in the organisation. 
This study found that lecturers working in both state and foundation universities had low levels of turnover intentions and high levels of organisational commitment. On examining the average values, it was found that lecturers had emotional commitment most-which was followed by normative commitment and continuance commitment respectively (see Tables 1-3).

The finding that academicians had high levels of organisational commitment obtained in this study shows that their individual targets and values were consistent with their organisational targets and values and that they consider their occupation not only as a job but also as a lifestyle. However, on considering the fact that the probability of losing capable workforce influences sustainable competition advantage in negative ways in institutions where the rate of quitting the job is high and that this situation causes organisational inefficiency (Bibby et al., 2007), having low levels of turnover intentions on the part of lecturers is a positive situation for universities.

At universities, which are the top of the educational sector - which is a sector concerned with humans in its field of activity, academicians performing the job of concerning with humans fulfil an important function in shaping the next generations. Considering this, it is evident that the levels of those employees' commitment to their organisation will be an important factor in both organisational development and in their efforts to do their job more willingly (Boylu et al., 2007).

The results obtained in this study are in parallel to the ones obtained in the literature. Ermiş et al. (2015) found that academicians' organisational commitment (-3.2) was high, their average scores for the sub-dimension of "emotional commitment" (-3.9) ranked first, and that their levels of "continuance commitment" was very low (-2.3). In a similar vein, Boylu et al. (2007), in their study performed at Gazi University, found that academicians' emotional commitment ( $\overline{\mathrm{X}}=3.65$ ) ranked first and that their continuance commitment $(\overline{\mathrm{X}}=2.63)$ ranked last. Ay et al. (2015) found that academicians' levels of commitment to their university were emotional commitment, normative commitment and continuance commitment respectively.

It was found that lecturers' turnover intentions differed significantly according to the type of university they work $\left(\mathrm{t}_{(274)}=4.481 ; \mathrm{p}<0.05\right)$. On analysing the average scores, it was found that the lecturers working in the faculties or departments of sports sciences of foundation universities $(9.82 \pm 4.15)$ had higher turnover intentions than those working in state universities (7.45 \pm 3.88 ) (see Table 5).

This result obtained can be attributed to the fact that work condition in foundation universities are more negative and that job security depends on a contract. It is emphasised in studies that job security should be increased in foundation universities and that the causes for dismissal from work should be clearly and fairly determined (Kilıç \& Gümüşeli, 2010).

It was found that academicians' emotional commitment $\left(\mathrm{t}_{(274)}=4.334 ; \mathrm{p}<0.05\right)$ and continuance commitment $\left(\mathrm{t}_{(274)}=3.596 ; \mathrm{p}<0.05\right)$ differed significantly according to the type of university they work in. Thus, lecturers working in state universities had higher levels of emotional commitment than those working in foundation universities. On the other hand, it was also found that the lecturers working in foundation universities (16.08 \pm 4.68$)$ had higher levels of continuance commitment than those working in state universities (13.80土4.76) (see Table 6).

Accordingly, it can be concluded that the variable of institution is influential in emotional commitment and continuance commitment and that the variable of the type of university is independent of normative commitment.

The fact that the academicians working in foundation universities have significantly higher levels of turnover intentions and continuance commitment shows that the results are supportive of each other.

Emotional commitment-the first component of organisational commitment-is described as employees' emotional interest in an organisation and as their desire to participate in and identify oneself with the organisation. Obligatory loyalty, the second component, is continuance commitment to an organisation stemming from an individual's perception of cost he/she has to pay in case he/she loses his/her job (Meyer, Allen, \& Topolnytsky, 1998). Accordingly, the fact that lecturers working in foundation universities always face the risk of being made redundant, that their continuance commitment which depends on benefits and earning is higher than the continuance commitment of lecturers working in state universities is both consistent with the theory and is an expected result. 


\section{References}

Allen, N. J., \& Meyer, J. P. (1990). Organizational Commitment: Evidence of Career Stage Effects. Journal of Business Research, 26(1), 46-91.

Allen, N. J., \& Meyer, J. P. (1991). A Three Component Conceptualization of Organizational Commitment. Human Resource Management Review, 1, 61-89. https://doi.org/10.1016/1053-4822(91)90011-Z

Ay, F. A., Ulusoy, H., \& Tosun, N. (2015). Akademisyenlerin Çalıştıkları Bölüme ve Üniversiteye Olan Örgütsel Bağlılık Düzeylerinin Bazı Değişkenlere Göre İncelenmesi. Uluslararası Sosyal Araştırmalar Dergisi, 36(8), 749-762.

Bartlett, K. R. (1999). The Relationship Between Training and Organizational Commitment In The Health Care Field. The Degree of Doctor of Philosophy, The University of Illınois, Urbana.

Bibby, J., Plsek, P., \& Whitby, E. (2007). Practical Methods for Extracting Explicit Design Rules Grounded in the Experience of Organizational Managers. The Journal of Applied Behavioral Science, 43(1). Retrieved from http://journals.sagepub.com/doi/pdf/10.1177/0021886306297013

Boylu, Y., Pelit, E., \& Güçer, E. (2007). Akademisyenlerin Örgütsel Bağlllık Düzeyleri Üzerine Bir Araştırma. Finans Politik \& Ekonomik Yorumlar, 44(511), 55-74.

Büyüköztürk, Ş. (2006). Sosyal Bilimler İçin Veri Analizi El Kitabı. Ankara: Pegem A Yayıncılık.

Cole, M. S., \& Bruch, H. (2006). Organizational İdentity Strength, İdentification, and Commitment and Their Relationships to Turnover İntention: Does Organizational Hierarchy Matter? Journal of Organizational Behavior, 27(5), 585-605. https://doi.org/10.1002/job.378

Das, D., Nandialath, A., \& Mohan, R. (2013). Feeling Unsure: Quit Or Stay? Uncovering Heterogeneity in Employees İntention to Leave in Indian Call Centers. The International Journal of Human Resource Management, 24(1), 15-34. https://doi.org/10.1080/09585192.2012.665067

Ermiş, S. A. (2014). Akademisyenlerin Örgütsel Bağlllık ve İs Tatmini Düzeyleri ve İlişkisi (Unpublished Master's Thesis). Gazi Üniversitesi/Sağlık Bilimleri Enstitüsü, Ankara.

Ermiş, S. A., Gokyurek, B., Sahin, M. Y., \& Yenel, F. (2015). The Examining of the Academics S Level on The Different Variables of Organizational Commitment: Sample of Physical Education. Science, Movement and Healt, 15(2), 528-533.

Gaertner, K. N., \& Nollen, S. D. (1989). Career Experiences, Perceptions of Employment Practices and Psychological Commitment to the Organization. Human Relations, 42(11), 975-991. https://doi.org/10.1177/001872678904201102

Hsiao, A., Auld, C., \& Ma, E. (2015). Perceived Organizational Diversity and Employee Behavior. International Journal of Hospitality Management, 48, 102-112. https://doi.org/10.1016/j.ijhm.2015.04.009

Joo, B. K., \& Park, S. (2010). Career Satisfaction, Organizational Commitment, and Turnover İntention: The Effects of Goal Orientation, Organizational Learning Culture and Developmental Feedback. Leadership \& Organization Development Journal, 31(6), 482-500. https://doi.org/10.1108/01437731011069999

Kılıç, S. Z., \& Gümüşeli, A. (2010). İstanbul İli Vakıf Üniversitelerine Bağlı Meslek Yüksekokullarında Görevli Öğretim Elemanlarının İş Doyum Düzeyleri. İstanbul Üniversitesi İşletme Fakültesi Dergisi, 39(2), 290-309.

Lingard, H., \& Lin, J. (2004). Career, Family and Work Environment Determinants of Organisational Commitment Among Women İn The Australian Construction İndustry. Construction Management and Economics, 22(4), 409-420. https://doi.org/10.1080/0144619032000122186

Liu, S., \& Onwuegbuzie, A. J. (2012). Chinese Teachers' Work Stress and their Turnover İntention. International Journal of Educational Research, 53, 160-170. https://doi.org/10.1016/j.ijer.2012.03.006

Marchiori, D., \& Henkin, A. (2004). Organizational Commitment of Health Profession Faculty: Dimensions,

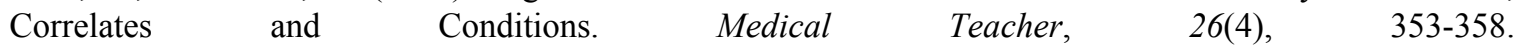
https://doi.org/10.1080/01421590410001683221

Meyer, J. P., \& Allen, N. J. (1997). Commitment in the Workplace Theory. In Research and Application. Sage Publications, Inc. London. 
Meyer, J. P., \& Allen, N. J. (2004). TCM Employee Commitment Survey Academic Users Guide. Department of Psychology, The University of Western Ontario.

Meyer, J. P., \& Stanley, D. J. (2002). Herscovitch, Lynne; Topolnytsky, Laryssa. Affective, Continuance, and Normative Commitment to the Organization: A Meta-analysis of Antecedents, Correlates, and Consequences. Journal of Vocational Behavior, 61, 20-52. https://doi.org/10.1006/jvbe.2001.1842

Meyer, J. P., Allen, N. J., \& Smith, C. A. (1993). Commitment to Organizations and Occupations: Extension and Test of a Three-Component Conceptualization. Journal of Applied Psychology, 78(4), 538-551. https://doi.org/10.1037/0021-9010.78.4.538

Meyer, J. P., Allen, N. J., \& Topolnytsky, L. (1998). Commitment in a Changing World of Work. Canadian Psychology/Psychologie Canadienne, 39(1-2), 83-93. https://doi.org/10.1037/h0086797

Özdemir, H., \& Yaylı, A. (2014). The Relationship Among Employees Loyalty, Performance and Turnover Intention. JRTR, $1(1), 48-58$.

Parasız, Ö., Koç, M., Ilgar, E., \& Şahin, M. Y. (2016). Relatıonshıp Between Organızatıonal Commıtment And Turnover Intentions of Academicians. The WEI International Academic Conference Proceedings May 30-31, in Prague, Czech Republic.

Rosin, H., \& Korabick, K. (1995). Organisational Experiences and Propensity to Leave a Multivariate İnvestigation of Men and Women Managers. Journal of Vocational Behaviour, 46(1), 1-16. https://doi.org/10.1006/jvbe.1995.1001

Schermerhorn, J. R., Hunt, J. G., \& Osborn, R. N. (1994). Managing Organization Behavior (5th ed.). John Willey \& Sons, Inc: New York.

Schwepker, C. H. (2001). Ethical Climate's Relationship to Job Satisfaction, Organizational Commitment, and Turnover İntention in the Salesforce. Journal of Business Research, 54, 39-52. https://doi.org/10.1016/S0148-2963(00)00125-9

Sökmen, A., \& Şimşek, T. (2017). Örgütsel Bağlllık, Örgütle Özdeşleşme, Stres ve İşten Ayrılma Niyeti İlişkisi: Bir Kamu Kurumunda Araştırma. İktisadi ve İdari Bilimler Fakültesi Dergisi, 18(3), 606-620.

Swailes, S. (2002). Organizational Commitment: A Critique of the Construct and Measures. International Journal of Management Reviews, 2(4), 155-178. https://doi.org/10.1111/1468-2370.00082

Tanriöver, U. (2005). The Effects of Learning Organization Climate and Self Directed Learning on Job Satisfaction, Affective Commit ment and Intention to Turnover (Master Dissertation). Marmara University, İstanbul.

Tett, R. P., \& Meyer, J. P. (1993). Job satisfaction, organizational commitment, turnover intention, and turnover: Path analyses based on meta-analytic findings. Personnel Psychology, 46, 259-293. https://doi.org/10.1111/j.1744-6570.1993.tb00874.x

Tolukan, E., Şahin, M. Y., \& Koç, M. (2016). Cimnastik Antrenörlerinin Örgütsel Özdeşleşme Düzeyleri ve İşten Ayrılma Niyeti İlişkisi. Turkish Studies, 11(8), 377-398. https://doi.org/10.7827/TurkishStudies.9558

Töremen, F., \& Demir, S. (2016). The Effects of Psychological Capital on Teachers' Intentions to Leave. Mustafa Kemal University Journal of Graduate School of Social Sciences, 34(13), 166-179.

Varol, F. (2010). Örgütsel Bağlllık ve İş Tatmininin Işten Ayrılma Niyetine Olan Etkisi: Konya İli İlaç Sektörü Çalışanları Üzerine Bir Uygulama (Unpublished Master Thesis). Sosyal Bilimler Enstitüsü, Konya, Selçuk Üniversitesi, Konya.

\section{Copyrights}

Copyright for this article is retained by the author(s), with first publication rights granted to the journal.

This is an open-access article distributed under the terms and conditions of the Creative Commons Attribution license (http://creativecommons.org/licenses/by/4.0/). 